\title{
BADAN USAHA SENTRA PENYULUHAN KEHUTANAN \\ PEDESAAN (SPKP) BENTENG WACU AWA DALAM \\ MEMBERDAYAKAN MASYARAKAT \\ (Studi di Desa Jaya Makmur Kecamatan Binongko \\ Kabupaten Wakatobi) \\ La Jeri, Bahtiar, Dewi Anggraeni \\ Jurusan Ilmu Kesejahtraan Sosial, Fakultas Ilmu Sosial Dan Ilmu Politik \\ Universitas Halu Oleo, Kendari \\ Jl. H. E. A. Mokodopit, Kendari 93232 \\ e-mail: jerykendari123@gmail.com
}

\begin{abstract}
ABSTRAK
Penelitian ini bertujuan untuk mengetahui fungsi badan usaha Sentra Penyuluhan Kehutanan Pedesaan (SPKP) Benteng Wacu Awa dalam memberdayakan masyarakat di Desa Jaya Makmur Kecamatan Binongko Kabupaten Wakatobi, dan untuk mengetahui hambatan-hambatan apa saja yang dihadapi Sentra Penyuluhan Kehutanan Pedesaan (SPKP) Benteng Wacu Awa dalam memberdayakan di Desa Jaya Makmur Kecamatan Binongko Kabupaten Wakatobi. Penelitian ini menggunakan metode penelitian kualitatif, yakni metode yang berlandaskan pada filsafat, digunakan untuk meneliti pada kondisi obyek yang alamiah, (sebagai lawannya adalah eksprimen) di mana peneliti adalah instrument kunci, teknik pengumpulan data dilakukan secara triangulasi (gabungan), analisis data bersifat induktif/kualitatif, dan hasil penelitian kualitatif lebih menekankan makna dan generalisasi. Dari hasil penelitian yang dilakukan diperoleh, bahwa fungsi badan usaha Sentra Penyuluhan Kehutanan Pedesaan (SPKP) Benteng Wacu Awa dalam memberdayakan masyarakat di Desa Jaya Makmur Kecamatan Binongko Kabupaten Wakatobi yakni fungsi komersial, fungsi sosial, dan fungsi pembangunan ekonomi. Sedangkan hambatan-hambatan yang dihadapi Sentra Penyuluhan Kehutanan Pedesaan (SPKP) Benteng Wacu Awa dalam memberdayakan masyarakat di Desa Jaya Makmur Kecamatan Binongko Kabupaten Wakatobi yaitu hambatan internal melalui terbatasnya sumber daya manusia, tidak tersedianya bahan baku, keterbatasan kemampuan manajerial, serta tidak adanya kemampuan mengelola peluang pasar yang ada dan terbatasnya modal usaha yang dimiliki. Sedangkan hambatan eksternal yakni akses Kelompok Usaha Bersama (KUB) sebagai mitra pemerintah, sebagai jembatan pemerintah dengan pengusaha kurang optimal dan belum ada pihak swasta yang memberikan bantuan modal sebagai usaha pemberdayaan ekonomi.
\end{abstract}

Kata Kunci: Badan Usaha, Pemberdayaan, Masyarakat.

\section{PENDAHULUAN}

Indonesia merupakan negara tropis yang memiliki hutan sangat banyak di setiap daerahnya. Kekayaan alam yang dimiliki oleh bangsa Indonesia sebagai salah satu paru-paru dunia, dan juga daerah hijau yang bisa melindungi bumi dari 
kekeringan. Hutan juga merupakan sumberdaya alam yang memberikan manfaat besar bagi kesejahteraan manusia, melalui tumbuhan seperti pohon, rumput, jamur, dan juga ekosistemnya lainnya.

Salah satu bentuk pemberdayaan terhadap masyarakat sekitar hutan yang efektif adalah melalui bentuk pemberdayaan kelompok.Pendekatan kelompok mempunyai kelebihan karena lebih luas daya jangkaunya, dan sesuai dengan budaya masyarakat pedesaan yang lebih komunal. Kelompok juga memiliki fungsi diantaranya sebagai wadah proses pembelajaran dan wahana dalam bekerjasama antar masyarakat, Utama dkk, dalam Yani (2017). Terbentuknya Sentra Penyuluhan Kehutanan Pedesaan (SPKP), diharapkan dapat memberikan ruang pembelajaran bagi masyarakat, khususnya mengenai pola-pola pemanfaatan sumberdaya alam hayati dan ekosistemnya secara arif dan bijaksana. Kehadiran SPKP adalah memberdayakan masyarakat dan lembaga di tingkat pedesaan untuk berpartisipasi aktif dalam penyelenggaraan pembangunan hutan dan kehutanan. Dalam melakukan pengelolaan hutan mangrove mulai dari pengambilan bibit, sampai pada proses penanaman mangrove mereka sangat gotong royong.

Pemberdayaan masyarakat ialah proses pembangunan di mana masyarakat berinisiatif untuk memulai proses kegiatan sosial untuk memperbaiki situasi dan kondisi diri sendiri. Pemberdayaan masyarakat hanya bisa terjadi apabila masyarakat itu sendiri ikut pula berpartisipasi. Partisipasi yang dimaksud disini adalah ikut terlibat aktif dalam kegiatan pemberdayaan yang dilakukan oleh Sentra Penyuluhan Kehutanan Pedesaan (SPKP) Benteng Wacu Awa seperti memproduksi Abon, Pengelolaan tulang Ikan Tuna menjadi makanan, usaha waserda dan pemasangan rumpon.

Sentra Penyuluhan Kehutanan Pedesaan (SPKP) adalah organisasi masyarakat di tingkat desa yang di bentuk berdasarkan hasil musyawarah berbagai pihak di wilayah desa dalam upaya melestaraikan fungsi dan manfaat hutan dan lahan untuk mewujudkan kesejahteraan masyarakat desa. SPKP (Sentra Penyuluhan Kehutanan Pedesaan) merupakan kelompok usaha yang di bentuk atas himbauan dari BTN (Balai Taman Nasional) Wakatobi dengan tujuan untuk melestarikan Hutan yang ada di Wakatobi baik hutan Mangrove maupun hutan 
lindung yang lain yang berada di Wakatobi pada Umumnya dan di Pulau Binongko pada Khususnya. Tidak hanya sebatas melestarikan Hutan, tetapi kelompok usaha ini juga mendirikan usaha seperti memproduksi Abon, Pengelolaan tulang Ikan Tuna menjadi makanan, Usaha waserda, dan pemasangan Rumpon. Patut kita syukuri dengan adanya kelompok usaha ini, masyarakat yang tadinya hanya memiliki pekerjaan sedikit atau yang tidak memiliki pekerjaan sama sekali (menganggur) terutama di kalangan ibu rumah tangga untuk membaca peluang dalam mendirikan usaha, dengan adanya kelompok usaha tersebut mereka sudah memiliki pekerjaan dan tentu juga memiliki pendapatan dari hasil usaha produk Abon tersebut sehingga dapat memperbaiki perekonomian rumah tangga. Selain memberikan manfaat bagi masyarakat SPKP Benteng Wacu Awa tentu memiliki kendala-kendala dalam hal memberdayakan masyarakat seperti keterbatasan modal, kurangnya akses untuk memasarkan hasil produk, keterbatasan kemampuan dan motivasi sumber daya manusia, serta kurangnya sarana dan prasarana.

SPKP Benteng Wacu Awa yang ada di Desa Jaya Makmur berdiri sejak tahun 2015 bulan November yang dimana telah banyak aktivitas kegiatanyang dilakukan yang berkaitan dengan kesejahteraan masyarakat. Keberadaan program SPKP tentunya memberikan dampak yang baik bagi masyarakat di desa Jaya Makmur, lalu bagaimanakah fungsi badan usaha Sentra Penyuluhan Kehutanan Pedesaan (SPKP) Benteng Wacu Awa dalam memberdayakan masyarakattersebut.

Atas dasar uraian di atas maka penulis tertarik untuk mengangkat penelitian dengan judul Fungsi Badan Usaha Sentra Penyuluhan Kehutanan Pedesaan (SPKP) Benteng WacuAwa Dalam Memberdayakan Masyarakat di Desa Jaya Makmur Kecamatan Binongko Kabupaten Wakatobi. Sehingga dengan demikian Rumusan masalah dalam penelitian ini yakni Bagaimana Fungsi dan Hambatan Badan usaha Sentra Penyuluhan Kehutanan Pedesaan (SPKP) Benteng Wacu Awa dalam memberdayakan masyarakat di Desa Jaya Makmur Kecamatan Binongko Kabupaten Wakatobi. 


\section{METODE PENELITIAN}

Penelitian ini dilaksanakan di Desa Jaya Makmur Kecamatan Binongko Kabupaten Wakatobi. Alasan memilih lokasi penelitian ini adalah karena di desa tersebut terdapat sebuah usaha SPKP (Sentra Penyuluhan Kehutanan Pedesaan) Benteng Wacu Awa dalam memberdayakan masyarakat dan ingin mengetahui fungsi badan usaha tersebut.

Jenis penelitian yang di pakai adalah penelitian kualitatif, teknik pengumpulan data dilakukan secara triangulasi (gabungan), analisis data bersifat induktif/kualitatif, dan hasil penelitian kualitatif lebih menekankan makna dari pada generalisasi. Makna adalah data yang sebenarnya, data yang pasti yang merupakan suatu nilai di balik data yang tampak

\section{PEMBAHASAN}

\section{Gambaran Umum Sentra Penyuluhan Kehutanan Pedesaan (SPKP) Benteng}

\section{Wacu Awa}

SPKP adalah organisasi masyarakat di tingkat desa yang bernaung dibawah Balai Taman Nasional Wakatobi (BTNW). SPKP Benteng Wacu Awa berdiri didesa Jaya Makmur di ketahui oleh pemerintah desa dan di SK kan oleh Kepala Desa. SPKP ini sebenarnya MDK (Model Desa Konservasi), jadi di Binongko itu MDK itu terdiri dari 2 MDK Koncu Pacua Wali dan MDK Benteng Wacu Awa.

Konservasi adalah pemeliharaan baik di darat maupun di laut, pemeliharaan di darat seperti penghijauan hutan mangrove dan kepiting kenari sementara di laut kimah, terumbu karang dan penyu.Jadi SPKP ini bernaung di desa dan di lembaga adat. SPKP Benteng Wacu Awa yang ada di Desa Jaya Makmur ini berdiri pada tanggal 17 November 2015 yang menaungi 2 kelompok yaitu kelompok nelayan dan kelompok pengrajin. Munculnya 2 kelompok dalam SPKP di Desa Jaya Makmur itu pada awalnya, desa tersebut sebagai penghasil ikan terbanyak di Binongko sehingga masyarakat tidak mampu membeli terkadang ikan itu sudah terbuang-buang sehingga muncul inisiatif SPKP Benteng Wacu Awa mengadakan kelompok Pengrajin Abon karena desa Jaya Makmur mempunyai nelayan sementara Abon itu bahan bakunya ikan jadi antara nelayan 
dan pengrajin serantai, nelayan yang mendatangkan atau mengusahakan ikan kelompok Abon yang memproduksinya.Jadi setelah masyarakat tidak mampu untuk membeli kelompok pengrajin yang membelinya dengan harga biasa.Oleh karena itu, nelayan mulai senang karena ada yang membeli ikan tersebut serta menampung.Sebenarnya SPKP Benteng Wacu Awa ini pengrajinnya itu bukan memproduksi Abon tetapi cukup saji maksudnya adalah seperti membuat penutupnya makanan (dalam bahasa cia-cia panamba). Namun yang menjadi kendala adalah di desa Jaya makmur tidak adak orang yang tau membuat penutupnya makanan tersebut akhirnya kelompok pengrajin tersebut menggantinya dengan produksi abon sebagai uji coba tetapi di lihat Abon tersebut setelah di pasarkan laku di masyarakat akhirnya mereka menetapkan sebagai salah satu aktivitasnya.

Adapun usaha SPKP Benteng Wacu Awa : usaha rumpon, waserda, stik tulang ikan, dan produksi abon selain itu ada juga aktivitas lain seperti pengambilan bibit mangrove sampai pada proses penanamannya dan membersihkan pantai. Balai Taman Nasional Wakatobi lah (BTNW)yang mempunyai andil dalam berdiri SPKP Benteng Wacu Awa di desa Jaya Makmur melalui sebuah musyawarah di tingkat desa. Setelah terbentuknya SPKP Benteng Wacu Awa maka pada saat itu juga di bentuk pengurus inti yang di pilih langsung oleh masyarakat dan terpilih 3 orang nama yaitu Muhama, Susiana, dan La Jadwan Bin Pandi. Berlanjut dari 3 orang nama tersebut mereka berembuk atau bermusyawarah kembali untuk memilih siapa ketua, sekretaris dan bendahara.

Adapun hasil dari musyawarah tersebut maka terpilih Muhama sebagai ketua, Susiana sebagai sekretaris, dan Jadwan Bin Pandi sebagai bendahara. Tidak bisa di pungkiri bahwa SPKP Benteng Wacu Awa mempunyai pendamping dan pendamping itulah yang digaji honor oleh BTNW. Kemudian SPKP Benteng Wacu Awa dibantu dan dibina oleh Balai Taman Nasional Wakatobi, baik itu dibantu anggaran maupun dibantu pikiran.

Fungsi Badan Usaha Sentra Penyuluhan Kehutanan Pedesaan (SPKP) Benteng Wacu Awa dalam Memberdayakan Masyarakat di Desa Jaya Makmur Kecamatan Binongko 
1. Fungsi Komersial

Fungsi komersial merupakan salah satu fungsi badan usaha yang bertujuan untuk memperoleh keuntungan.Dalam memperoleh keuntungan, badan usaha harus mengelola sumber daya produksi yang tersedia secara efektif dan efisien sesuai dengan prinsip-prinsip manajemen.

\section{Fungsi Sosial}

Fungsi sosial merupakan fungsi badan usaha yang berhubungan dengan manfaat badan usaha secara langsung atau tidak langsung terhadap kehidupan masyarakat.Dalam fungsi ini, badan usaha SPKP tidak hanya memanfaatkan tenaga dan pikiran anggota untuk kemajuan badan usaha semata, tapi juga memperhatikan kualitas dan masa depan anggota. Adanya Badan Usaha SPKP di Desa Jaya Makmur ditanggapi positif oleh masyarakat Desa Jaya Makmur.Menurut mereka dengan adanya badan usaha ini memberikan manfaat positif.

3. Fungsi Pembangunan Ekonomi

Fungsi ini lebih ditekankan pada peran badan usaha dalam pembangunan ekonomi pemerintahan.Bagaimana badan usaha memberikan peningkatan ekonomi masyarakat, apakah itu badan usaha milik swasta apalagi badan usaha milik pemerintah. Badan usaha yang didirikan di daerah-daerah tertinggal juga secara langsung akan berdampak pada pemerataan ekonomi.

\section{Hambatan-Hambatan Sentra Penyuluhan Kehutanan Pedesaan (SPKP) Benteng Wacu Awa dalam Memberdayakan Masyarakat di Desa Jaya Makmur Kecamatan Binongko}

1. Hambatan Internal

Hambatan internal merupakan suatu hambatan yang berasal dari dalam badan usaha itu sendiri. Adapun hambatan-hambatan internal yang terjadi dalam proses pemberdayaan badan usaha SPKP Benteng Wacu Awa di Desa Jaya Makmur kecamatan Binongko yakni :

a. Terbatasnya Sumber Daya Manusia

Sumber daya manusia merupakan modal dasar pembangunan nasioanal.Oleh karena itu, kualitas sumber daya manusia senantiasa harus 
dikembangkan dan diarahkan agar bisa mencapa tujuan yang diharapkan. Sumber daya manusia adalah semua manusia yang ada di dunia yang mampu berniat dan mau meluangkan diri untuk melakukan suatu pekerjaan yang bermanfaat buat diri sendiri dan orang lain, terpacu dari daya pikir dan daya fisik yang dimiliki pribadi manusia masing-masing.Salah satu bentuk hambatan pemberdayaan yang terjadi di SPKP Benteng Wacu Awa yaitu terbatasnya sumber daya manusia.

b. Tidak Tersedianya Bahan Baku

Bahan baku adalah barang-barang yang akan menjadi bagian dari produk jadi yang dengan mudah dapat diikuti biayanya.Bahan baku merupakan bagian terpenting dalam sebuah produsi. Tanpa bahan baku sebuah produksi tidak akan berjalan. Tidak tersedianya bahan baku merupakan salah satu faktor penghambat dalam memproduksi. Oleh karena itu, bahan baku yang sering menjadi kendala atau susah di dapat dalam proses produksi Abon di SPKP Benteng Wacu Awa Desa Jaya Makmur adalah Ikan.

Desa Jaya Makmur yang merupakan salah satu desa yang termasuk dalam pulau terpencil yang jauh dari pusat perkotaan, sehingga tidak terdapat Supermarket atau pusat-pusat perbelanjaan lainnya.Hal ini menjadi penghambat bagi badan usaha SPKP Benteng Wacu Awa dalam memperoleh bahan-bahan produksi.

c. Keterbatasan Kemampuan Manajerial

Kemampuan manajerial adalah sebuah kemampuan untuk mengatur, mengkordinasikan dan menggerakan para bawahan kearah pencapaian tujuan yang telah ditentukan. Kemampuan manajerial lahir dari suatu proses panjang yang terjadi secara perlahan-lahan melalui proses pengamatan dan pembelajaran.

d. Tidak Adanya Kemampuan Mengelola Peluang Pasar yang Ada dan

Terbatasnya Modal Usaha yang Dimiliki

Peluang pasar adalah pasar sasaran yang di dalamnya terdapat keinginan dan kebutuhan yang ingin dipenuhi.Suatu badan usaha perlu menganalisa atau membaca peluang pasar yang dapat dimanfaatkan. Membaca peluang pasar merupakan hal penting, karena dengan itu suatu badan usaha dapat 
Jurusan Ilmu Kesejahteraan Sosial

mengetahui apakah produk yang diciptakan mempunyai peluang untuk dipasarkan dan dengan membaca peluang pasar badan usaha juga dapat mengetahui apa yang sedang dibutuhkan oleh konsumen.

Modal usaha juga menjadi faktor penting dalam pengembangan badan usaha.Suatu badan usaha tidak dapat bergerak dalam hal ini tidak dapat menghasilkan produk-produk tanpa memiliki modal.Bahkan, modal menjadi faktor utama penentu suatu keberhasilan badan usaha.

Badan Usaha SPKP Benteng Wacu Awa Desa Jayamakmur dalam hal pemasaran produk melalui offline maupun online. Pemasaran secara offline, seperti dijual atau dititipkan pada beberapa kios milik masyarakat, sedangkan pemasaran secara online dilakukan dengan jalur promosi lewat beberapa akun media sosial seperti Instagram, Facebook, twitter dan WhatsApp. Namun, pemasaran produk masih belum berjalan lancar.Antara jumlah produk yang dihasilkan lebih banyak dan tidak sebanding dengan jumlah konsumen.

2. Hambatan Eksternal

Hambatan eksternal merupakan hambatan-hambatan yang berasal dari luar badan usaha itu sendiri.Adapun hambatan-hambatan eksternal yang terjadi dalam proses pemberdayaan badan usaha SPKP Benteng Wacu Awa di Desa Jaya Makmur kecamatan Binongko, yakni :

a. Akses Kelompok Usaha Bersama (KUB) sebagai Mitra Pemerintah, sebagai Jembatan Pemerintah dengan Pengusaha Kurang Optimal.

Kerjasama suatu badan usaha dengan mitra pemerintah sangat penting bagi kemajuan badan usaha itu sendiri.Suatu badan usaha hendaknya memilki akses mitra kerja dengan pihak pemerintah.Hal ini menjadi penunjang bagi perkembangan suatu badan usaha.Kurang optimalnya akses kerjasama badan usaha dengan pihak pemerintah bisa menjadi penghambat berkembangnya badan usaha itu sendiri.

Badan usaha SPKP Benteng Wacu Awa Desa Jaya Makmur bekerjasama dengan pihak pemerintah daerah melalui pihak Balai Taman Nasional wakatobi (BTNW).BTNW membantu SPKP Benteng Wacu Awa Desa Jaya Makmur dengan memberikan bantuan modal.Dengan bantuan modal yang 
diberikan oleh BTNW kepada SPKP Benteng Wacu Awa, sehingga badan usaha ini tidak lagi mengalami kendala terkait modal.

b. Belum Ada Pihak Swasta yang Memberikan Bantuan Modal sebagai Usaha Pemberdayaan Ekonomi.

Sebuah badan usaha dalam hal pemberdayaan ekonomi hendaknya bekerjasama dengan pihak swasta.Kerjasama suatu badan usaha dengan pihak swasta sangat membantu kemajuan badan usaha itu sendiri.Hal ini dapat menjadi salah satu penunjang bagi perkembangan suatu badan usaha. Badan usaha SPKP Benteng Wacu Awa Desa Jaya Makmur sejauh ini belum menerima bantuan apapun dari pihak swasta, baik bantuan modal maupun materi lainnya.

\section{KESIMPULAN}

Berdasarkan analisis hasil penelitian yang telah diuraikan sebelumnya, dapat disimpulkan bahwa:

1. Fungsi Badan Usaha Sentra Penyuluhan Kehutanan Pedesaan (SPKP) Benteng Wacu Awa sangat berfungsi dalam memberdayakan masyarakat Desa Jaya Makmur, Kecamatan Binongko Kabupaten Wakatobi. Jika ditinjau dari : a) fungsi komersial yaitu memberikan keuntungan kepada masyarakat yang bekerja di SPKP Benteng Wacu Awa tersebut melalui hasil penjualan Abon, b) fungsi sosial yaitu memberikan pengetahuan, lapangan pekerjaan, keterampilan melalui pelatihan yang dilakukan oleh SPKP Benteng Wacu Awa, c) fungsi pembangunan ekonomi yaitu meningkatkan ekonomi masyarakat dan membantu pemerintah Desa Jaya Makmur dalam mengimplentasikan visi dan misinya.

2. Adapun hambatan-hambtan yang dihadapi SPKP Benteng Wacu Awa dalam memberdayakan masyarakat di Desa Jaya Makmur Kecamatan Binongko Kabupaten Wakatobi terdiri dari hambatan internal dan hambatan eksternal. Hambatan internal, meliputi : a) terbatasnya sumberdaya manusia yakni masih minimnya pengetahuan dalam pengembangan kreativitas-kreativitas baru serta tidak mampu mengelola waktu dengan baik, b) tidak tersedianya bahan baku yakni bahan baku susah di dapat pada saat musim-musim tertentu, c) keterbatasan 
kemampuan manajerial yakni ini bagi mereka tidak menjadi kendala sebab mereka mampu mengendalikan memanajemen dengan baik, dan d) tidak adanya kemampuan mengelola peluang pasar yang ada dan terbatasnya modal usaha yang dimiliki yakni kurangnya kemampuan dalam memanfaatkan peluang pasar untuk menjual hasil produksinya. Sedangkan, hambatan eksternal meliputi : a) akses kelompok usaha bersama (KUB) sebagai mitra pemerintah, sebagai jembatan pemerintah dengan pengusaha kurang optimal yakni belum terbangun komunikasi yang baik pengusaha-pengusaha dalam menjalankan usaha bersama demi tercapainya sebuah tujuan yang diinginkan, b) belum ada pihak swasta yang memberikan bantuan modal sebagai usaha pemberdayaan ekonomi yakni belum terbangunnya kerjasama dengan pihak swasta sebagai pemberi modal untuk kemajuan usaha.

\section{Saran}

Berdasarkan hasil penelitian yang telah dilakukan terkait dengan fungsi badan usaha sentra penyuluhan kehutanan pedesaan (SPKP) Benteng Wacu Awa dalam memberdayakan masyarakat di Desa Jaya Makmur Kecamatan Binongko Kabupaten Wakatobi, maka saran yang akan diberikan peneliti yakni :

1. Kepada pemerintah setempat agar kiranya mencarikan pasaran abon yang seluas-luasnya serta melakukan pemberdayaan kepada seluruh anggota SPKP Benteng Wacu Awa berupa pelatihan, dan keterampilan kerja, hal tersebut di lakukan agar para anggota menjadi lebih produktif.

2. Kepada seluruh baik Ketua, Sekretaris, Bendahara, dan anggota SPKP Benteng Wacu Awa mengutamakan pendidikan agar tercipta kualitas sumber daya manusia yang baik.

\section{DAFTAR PUSTAKA}

Artikel Jurnal

Cholisin.2011. Pemberdayaan masyarakat. Disampaikan Pada Gladi Manajemen Pemerintahan Desa Bagi Kepala Bagian/Kepala Urusan Hasil Pengisian Tahun 2011 Di Lingkungan Kabupaten Sleman, 19-20 Desember 2011 
Martono Edhi dkk. 2015. Pemberdayaan Masyarakat Melalui Pengembangan

Desa Wisata Dan Implikasinya Terhadap Ketahanan Sosial Budaya

Wilayah (Studi Di Desa Wisata Penglipuran Bali). JURNAL

KETAHANAN NASIONAL

Mustangi, dkk. 2017. Pemberdayaan Masyarakat Berbasis Potensi Lokal Melalui

Program Desa Wisata di Desa Bumiaji. Sosioglobal jurnal pemikiran dan penelitian sosiologi. Departemen of Sociology, Faculty of Social and

Political Science, Universitas Padjadjaran

Sugiyono. 2017. Metode Penelitian Kuantitatif, Kualitatif, dan R\&D. Bandung:

Alfabeta, CV

Suharto, Edi. 2014. Membangun masyarakat memeberdayakan rakyat. Bandung : PT Refika Aditama

Upe. 2016. Metode Penelitian SosialMokoau-Kendari: Literacy Institute

Yani, dkk. 2017. Dinamikakelompok sentrapenyuluhan kehutanan dan pedesaan manggadelimataman nasionalkarimun jawa. Tanggerang Selatan : Program StudiAgribisnis UniversitasTerbuka

\section{Sumber Internet}

https://rismajayanti.wordpress.com/2012/01/15/penyuluhan/Diakses pada tanggal 04 November 2018

(https://informasiana.com/fungsi-badan-usaha/\#) Diakses pada tanggal 15 Desember 2018

https://www.maxmanroe.com/vid/bisnis/pengertian-badan-usaha.htmlDiakses pada tanggal 15 Desember 2018

(http://pengertianahli.id/2014/01/pengertian-jenis-fungsi-badan-usaha.html\#) Di akses pada tanggal 15 Desember 2018. 